\title{
Kant and the Second Person
}

ABSTRACT: According to Stephen Darwall's second-personal account, moral obligations constitutively involve relations of authority and accountability between persons. Darwall takes this account to lend support to Immanuel Kant's moral theory. Critics object that the second-personal account abandons central tenets of Kant's system. I respond to the three main challenges that critics offer by showing that they rest on misunderstandings of the second-personal account. Properly understood, this account is not only congenial to Kant's moral theory, but also illuminates aspects of that theory which have hitherto received scant attention. In particular, it motivates a fresh perspective on the relationship between respect, persons, and the law.

KEYWORDS: Stephen Darwall, Immanuel Kant, obligation, second-person standpoint, respect

\section{Introduction}

According to Stephen Darwall's second-personal account, moral obligations implicate a distinct class of practical reasons, 'second-personal reasons', whose 'validity depends on presupposed authority and accountability relations between persons and, therefore, on the possibility of the reason's being addressed person-to-person' (Darwall 2006: 8). In other words, obligations constitutively involve persons' legitimate demands on one another.

Darwall cites Kant as his philosophical ally. Indeed, he argues that Kant's project of deriving moral obligations from the form of practical reason cannot succeed unless it invokes the notion of a second-personal reason. In this essay, I discuss the arguments of Darwall's Kantian critics, who object that the second-personal account abandons central tenets of Kant's moral theory. In a nutshell, these critics argue that, in Kant's moral theory, moral consideration of others is downstream of the moral law, whose source resides in pure practical reason alone. They conclude that Kant's moral theory is decidedly first-personal, not second-personal.

I argue that the second-personal account is more congenial to Kant's moral theory than these critics suppose. I respond to the three main challenges to the

For helpful feedback, I am grateful to Rowan Cruft, Stephen Darwall, Michael Gregory, Suzanne Jacobi, Pauline Kleingeld, Stefano Lo Re, Ben Sachs, Jens Timmermann, Fiorella Tomassini, an audience at the conference Humanity and Personality in Kant at the University of Lisbon, and two anonymous reviewers. My work was supported by grant VC.GWI7.059 from the Dutch Research Council (NWO). Although I quote from modern translations of Kant, in addition to citations to these sources, for specialist readers I provide the pagination of the Prussian Academy Edition with the following abbreviations for the works: G for Groundwork of the Metaphysics of Morals; CPrR for Critique of Practical Reason; MM for Metaphysics of Morals; Rel for Religion within the Bounds of Bare Reason. 
second-personal account's Kantian credentials. My responses show that these challenges are based on misunderstandings of the second-personal account. Understood correctly, this account not only is compatible with the central tenets of Kant's moral theory, but it also illuminates some aspects of this theory that have hitherto received scant attention. In particular, it sheds new light on the relationship between respect for persons and respect for the law in Kant's theory, by inspiring the reading that, on this theory, the law is the formal principle of the person.

In what follows, after outlining the second-personal account (section I), I respond to the three main challenges to this account's Kantian credentials. The first challenge is the objection that, for Kant, moral obligations are based on the principle of pure practical reason, not on the demands of others (section 2 ). The second challenge consists in the accusation that the second-personal account narrowly construes moral obligations on the model of perfect duties to others, or even duties of right, and therefore cannot accommodate features of Kant's moral theory that stem from its agent-centered orientation, namely the primacy of duties over rights, imperfect duties, and duties to oneself (section 3). The third challenge is that Kant takes the ultimate object of the feeling of respect to be the moral law, not persons (section 4). I end by arguing that the second-personal account is not only compatible with the central tenets of Kant's moral theory, but also promises to shed new light on some of its features (section 5 ).

\section{The Second-Personal Account}

Darwall's second-personal account invokes a conceptual link between obligation and accountability: an agent is obligated to $\varphi$ if and only if she can legitimately be held accountable for failing to $\varphi$ without excuse. Importantly, this need not mean that the agent can be punished or otherwise sanctioned if she fails to $\varphi$ (Darwall 2006: 250). Instead, it means that failure to live up to her obligations warrants the adoption of certain types of reactive attitudes, such as blame and resentment, toward the agent (also see Strawson I962). The relevant types of reactive attitudes implicitly address a claim or demand to the agent, summoning her to act in a certain way. In Darwall's words, they come with 'an implicit RSVP' in that they 'aim to draw [the agent] into an exchange that will constitute their being held accountable' (2006: I45).

Darwall argues that the only way to account for the conceptual link between obligation and accountability is to recognize that an act's being obligatory is grounded in facts about relations of authority and accountability. More specifically, the normative reasons implicated by moral obligations are second-personal in that their 'validity depends on presupposed authority and accountability relations between persons and, therefore, on the possibility of the reason's being addressed person-to-person' (Darwall 2006: 8). This implies that the authority to hold an agent accountable for compliance with her obligations is an irreducibly second-personal, practical authority. It is irreducibly second-personal in that the reason it addresses constitutively involves the relation of authority and accountability between the addresser and the addressee. It is 
practical in that it 'creates a distinctive reason for compliance' (2006: I I). Although the content of our obligations is of course informed in part by substantive considerations, such as how our actions affect persons' well-being, Darwall thinks that these considerations are relevant only insofar as they authorize demands. Darwall tentatively suggests that they do so if and only if they pertain to persons' interests qua beings with second-personal authority (2006: 309-10).

Darwall argues that the second-personal account vindicates Kant's claim that the categorical imperative is the supreme principle of moral obligation. His argument depends on the observation that 'second-personal address', the activity of addressing a second-personal reason by making a demand, is subject to 'normative felicity conditions' (2006: 5). These are conditions that must be met for an instance of second-personal address to succeed at addressing a second-personal reason. And crucially, according to Darwall, these conditions coincide with Kant's conditions of the possibility of moral obligation: autonomy of the will and the supreme authority of the categorical imperative (2006:275).

Darwall's argument for this claim starts from his observation that, when we hold someone accountable for complying with her obligation to $\varphi$, we must implicitly presuppose that she can hold herself accountable for failing to $\varphi$ without excuse. The reason is that holding an agent accountable differs in important ways from coercing or otherwise 'goading' him (Darwall 2006: 49-52). In goading an agent, we are attempting to get him to act in a certain way by announcing that we will act in a way or bring about a state of the world that he regards as desirable (or undesirable) if he complies (or fails to comply). That is, we are appealing to the ways in which the agent evaluates actions or states of affairs independently of our authority to address him. By contrast, when we hold an agent accountable, we are trying to influence his behavior by getting him to appreciate, freely and rationally, the legitimacy of our demand.

This observation can be illustrated with one of the examples that Darwall uses (2006: 5-10). Suppose one person, Arnold, is standing on top of the foot of another person, Bella. Darwall's observation is that when Bella demands that Arnold remove his foot from on top of hers, thus holding him to his obligation to do so, she implicitly presupposes that Arnold can demand this of himself.

Now, according to the second-personal account, when Bella holds Arnold accountable, she addresses a second-personal reason to him. That is, she addresses a reason to him that would not exist 'but for her authority to address it' (Darwall 2006: I3). From this, in conjunction with the difference between holding accountable and goading, Darwall concludes that by addressing Arnold second-personally, Bella is trying to get him to determine himself, freely and rationally, by her authority to address him in this way. Thus, Bella's demand presupposes that Arnold can internalize Bella's authority within his deliberation. But this means that her demand must be addressable from a perspective that Bella and Arnold, addresser and addressee, can share (Darwall 2006: I I I-I 5).

This shared perspective is what Darwall calls the 'second-person standpoint' (2006: II4). This standpoint facilitates a mode of reasoning that is irreducibly second-personal in that it is guided exclusively by the shared second-personal authority of persons. For Darwall, it is this authority, not a substantive value or 
normative requirement, in which our dignity as persons most fundamentally consists (2006: I3-I4). Crucially, Darwall contends that a demand is addressable from the second-person standpoint if and only if it is warranted by the categorical imperative (2006: 275-76). Accordingly, he contends, 'second-personal competence', the capacity to determine oneself by demands addressable from within the secondperson standpoint, involves autonomy of the will (Darwall 2006: 275-76).

Darwall's argument for this contention emphasizes that, as a corollary of the second-personal nature of accountability, holding persons accountable presupposes 'that there was a process of reasoning they could have engaged in by which they could have held themselves responsible and determined themselves to act as they should have' (2006: 24I). Since this process of reasoning is supposed to be determined solely by our shared authority as participants in second-personal address, Darwall argues, it must proceed independently of the content of particular demands (2006: 275). Instead, it must be guided by the question of what participants in second-personal address as such can demand of one another. Therefore, according to Darwall, second-personal competence involves autonomy of the will, which Kant defines as 'the characteristic of the will by which it is a law to itself (independently of any characteristic of the objects of willing)' (Kant 20I I:

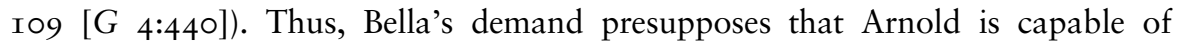
determining himself by the mere form of law, and thus of following the formula of universal law: 'act only according to that maxim through which you can at the same time will that it become a universal law' (Kant 20I I: 7I [G 4:42I]). What is more, this capacity must be realized when Arnold acts on Bella's demand; that is, the obligation that Bella's demand addresses must be underpinned by the categorical imperative.

In this way, the second-personal account purports to vindicate Kant's claim that our moral obligations derive from a 'formal' rather than a 'material' principle of the will, which commands that we choose our maxims as if we were thereby at the same time making laws for all persons at all times (Kant I 996a: I 53-64 [CPrR 5:I9-30]; Darwall 2006: 275). Darwall writes, "[N]orms of moral obligation are "laws" for a "kingdom of ends", which structure and define the equal dignity of persons as beings who may not be treated in some ways and must be in others and who have equal standing to demand this second-personally of one another' (2006: IOI).

Yet, it is important to note that Darwall does not claim that the second-personal account is identical to Kant's moral theory. He claims that his account supports Kant's moral theory. Indeed, he even claims that Kant needs the second-personal account (2006: 213-42; Darwall 2009). For Darwall thinks that his analysis of obligations in terms of second-personal reasons is the only way to establish the link between moral obligation on the one hand and the twin notions of the categorical imperative and autonomy of the will on the other hand. But this means that, to the extent to which Kant can be read as attempting to vindicate autonomy and the categorical imperative without appealing to the notion of a second-personal reason, Darwall also distances himself from Kant.

To appreciate how Darwall sees his relation to Kant, it helps to consider Kant's fact-of-reason argument. This argument purports to vindicate autonomy of the will and the categorical imperative on the basis of our consciousness of being 
bound by the moral law. Kant invites us to imagine an agent whose prince threatens to have him executed unless he 'give[s] false testimony against an honorable man' (Kant I996a: I63-64 [CPrR 5:30]). Kant argues that, while the agent may or may not succumb to the prince's threat, he would have to admit that he can resist it. The reason is that the agent realizes that he ought to resist the threat, and 'ought' implies 'can'. But, according to Kant, the agent can refuse the prince's demand only if he possesses autonomy of the will. And if he possesses autonomy of the will, then he is bound by the categorical imperative.

Whether Darwall can endorse this argument depends on how the 'ought' that the agent recognizes—the alleged 'fact of reason' (Kant I996a: I64 [CPrR 5:3 I]) —is interpreted (see Darwall 2006: 235-42). If this 'ought' is interpreted as implicating an obligation in the irreducibly second-personal sense, Kant's argument is not only compatible with but supported by the second-personal account. For, by recognizing that he is obligated to resist the prince's threat in this sense, the agent also recognizes that he can be held accountable for doing so from within the second-person standpoint. And, as we have seen, Darwall thinks that this recognition indeed presupposes that the agent possesses autonomy of the will.

By contrast, if the 'ought' in question is interpreted more broadly, as reflecting some sort of normative reason or requirement, where this does not already entail the agent's accountability for resisting the prince's threat, then Darwall rejects Kant's fact-of-reason argument. Suppose the 'ought' is read as merely reflecting the sort of reason that we need in order to count as acting at all. According to Darwall, this cannot establish the agent's autonomy of the will because we can count as acting without being guided by reasons that purport to derive their normativity from the form of our will (Darwall 2006: 222-29, pace Korsgaard I996, 2007, 2009). For example, we can intelligibly act for reasons that purport to be normative solely by virtue of intrinsic features of the actions or outcomes that they favor. Alternatively, suppose the 'ought' invoked by the fact-of-reason argument is taken to invoke a normative requirement akin to a Rossian prima-facie duty. Since such a requirement purports to bind us by virtue of intrinsic features of the actions it requires or forbids, the agent's ability to act on them does not require autonomy either (Darwall 2006: 239; see Ross 2002). (For critical discussions of Darwall's rejection of these interpretations of the fact-of-reason argument, see Grenberg [2013: ch. 9]; Korsgaard [2007]; Pauer-Studer [20IO]; Schapiro [20IO]; Timmermann [20I4: I42-45]. For replies to some of these, see Darwall [2007, 20Iob].)

Thus, the second-personal account approves of the fact-of-reason argument, but only if it is interpreted second-personally. Since the fact-of-reason argument always proceeds from the first-person standpoint of an individual agent, it follows that the second-personal account does not rule out a first-personal vindication of Kant's moral theory. Indeed, the second-person standpoint is a first-person standpoint (Darwall 2007: 55). What the second-personal account rules out is a 'merely first-personal' vindication of Kant's moral theory, i.e., one that proceeds from a standpoint which is not already colored, so to speak, by the agent's place in relations of authority and accountability (Darwall 2006: I0, my emphasis). 
Insofar as Kant himself does not explicitly rely on the conceptual link between obligation and accountability, the second-personal account must be taken at least to add something to the Kantian tradition. The remainder of this essay is concerned with the question of whether the second-personal account thereby also abandons central aspects of Kant's moral theory, as Darwall's Kantian critics argue.

\section{The Source of Obligations}

The first challenge to the thesis that the second-personal account is congenial to Kant's moral theory is posed by the argument that, for Kant, moral obligations have their source, not in persons' authority, but in pure practical reason. As Oliver Sensen puts it, 'Making a claim does not by itself generate an obligation for the agent. For Kant, the bindingness arises through the qualification of the claim as a universal law, as commanded by the Categorical Imperative' (20II: I2I, my emphasis). Sensen concludes that '[i]n this sense, Kant's ethics is not second-personal' (20II: I20). Because the moral law is the formal principle of the agent's own practical reason, the ultimate source of our moral obligations is in pure practical reason rather than in the claims or demands of others.

Sensen's objection presupposes a voluntarist reading of the second-personal account. According to this reading, Bella's demand that Arnold remove his foot, by itself, puts Arnold under an obligation to remove his foot. However, the voluntarist reading is not correct. Darwall does not depict the demands of persons as giving rise to moral obligations by themselves. To the contrary, as I explained in the previous section, he takes the categorical imperative and autonomy of the will to 'mediate second-personal relations' as 'the necessary conditions for the possibility of second-personal authority' (Darwall 2006: 242).

Again, the second-personal account is not identical to Kant's view, because it regards obligation, the categorical imperative, and autonomy as importantly linked to accountability. This is the sense in which, according to Darwall, 'the dignity of persons' is 'the fundamental moral notion' (2006: 242). But this does not commit him to abandoning Kant's claim that obligations have their source in pure practical reason. For Darwall does not conceive of the dignity of persons as a substantive value or a set of normative requirements that binds us independently of the formal principle of practical reason. Any claims that persons can legitimately make on us presuppose our second-personal competence, and thus our autonomy, as a necessary condition of the possibility of their second-personal authority (Darwall 2006: 242). Contrary to what Sensen seems to think, Darwall agrees with Kant that 'I can recognize that I am under obligation to others only insofar as I at the same time put myself under obligation' (Kant I996b: 543 [MM 6:4I7-I 8]; Darwall 2006: 248n9; pace Sensen 20II: I22).

\section{Rights and Duties}

The next challenge to the thesis that the second-personal account is congenial to Kant's moral theory consists of a bundle of three separate objections. What these objections have in common is that, in one way or another, they are motivated by 
the assumption that the second-personal account takes a specific subset of obligations as its paradigm. In particular, they assume that the second-personal account narrowly focuses on obligations that we owe to others such that others can in some sense exact their fulfilment from us. Within Kant's moral theory, these obligations correspond to the category of perfect duties to others or, perhaps even more narrowly, to those duties that can be enforced, namely duties of right. Whether all perfect duties to others are also duties of right is a complicated exegetical issue that I cannot address here (see, for example, Willaschek I997).

On the basis of this assumption, the three objections accuse the second-personal account of abandoning features of Kant's moral theory that stem from its agent-centered orientation. These features are the primacy of duties over rights, imperfect duties, and duties to oneself. Below, I respond to the three objections by challenging the assumption that the second-personal account takes a narrow subset of duties as its paradigm.

The clearest and most comprehensive statement of the three objections is provided by Jens Timmermann (2OI4). For this reason, my discussion in this section directly responds to his arguments. I note that Timmermann himself entertains the possibility that these arguments presuppose a reading of the second-personal account that does not reflect Darwall's own view (Timmermann 20 I 4: I46-47). However, this reading of the second-personal account seems to be widely shared in Kantian practical philosophy. Among Kantians, it is commonly assumed that, by definition, only duties to others are second-personal (see, for example, Bacin 2015: I05; Ebels-Duggan 2009: 9n36; Flikschuh 2017: 78n29; Ripstein 2009: Io9nI). Some authors even explicitly tie the second-personal account to the sphere of juridical duties, as opposed to morality as whole (see, for example, Flikschuh 2017: 78n29; Pauer-Studer 2010: 300-2; Ripstein 2009: I09nI). By discussing Timmermann's arguments, I thus take myself to be addressing a view that is held by a sizeable group of theorists.

\section{I The Primacy of Duties}

The first feature of Kant's agent-centered system that the second-personal account is accused of failing to accommodate is the primacy of duties vis-à-vis rights (Timmermann 2014: I36-37). Kant provides the following brief argument for the claim that duties are prior to rights: '[W]e know our own freedom (from which all moral laws, and so all rights as well as duties proceed) only through the moral imperative, which is a proposition commanding duty, from which the capacity for putting others under obligation, that is, the concept of a right, can afterwards be explicated' (I996b: 395 [MM 6:239]). According to Kant, then, we do not find out about our duties by attending to others' rights. Instead, we encounter our duties directly within our own practical consciousness, in the form of an imperative, and only against this background can others intelligibly assert their rights.

As Kantian theorists have criticized, recent theories of human rights tend to ignore this point by regarding rights as prior to duties (Hope 20I3; O’Neill I996). Although Darwall does not primarily frame his position in terms of rights, 
Timmermann contends that the second-personal account 'parallels' these theories because it regards 'moral obligations as based on second-personal claims' (Timmermann 20I4: I36). I call this supposed parallel into question. It rests on the assumption that the type of second-personal authority that Darwall takes to be constitutive of moral obligations plays the same role within the second-personal account as rights do within Kant's moral system. To see what this assumption amounts to, let us briefly recapitulate Kant's account of rights.

For Kant, rights belong to the domain of juridical lawgiving, which he distinguishes from ethical lawgiving (I996b: 383-85 [MM 6:2 I8-2I]). Ethical or internal lawgiving pertains directly to maxims, ends and incentives, and only indirectly to actions. More specifically, to fulfil an ethical duty, it is not enough to perform a certain action; it is also necessary that one performs it from the right motivation, namely from the feeling of respect for the moral law. Accordingly, ethical duties cannot be enforced. If an agent performs the required action from an 'external incentive', such as the fear of punishment, her determining ground is not the moral law but some contingent desire (I996b: 384 [MM 6:219]). By contrast, juridical or external lawgiving is concerned solely with external actions. Accordingly, juridical duties can be enforced; all that counts is that the agent perform the required action, not that she be guided by a specific maxim, end, or incentive. Indeed, for Kant, the notion of right is conceptually tied not only to the possibility but to the justification of coercion: 'Right and authorization to use coercion therefore mean one and the same thing' (Kant I996b: 389 [MM 6:232]).

Kant also thinks that juridical duties belong to the sphere of duties that are owed to someone (Kant I996b: 382 [MM 6:227]; see Ripstein 2009: I09; Timmermann 20I4: I36). In the current literature, such duties are commonly referred to as directed duties, or duties to someone, because their violation is not only wrong but wrongs someone. In sum, then, to say that Bella has a Kantian right against Arnold that he remove his foot is to say that Arnold has a juridical duty, owed to Bella, to remove his foot. And this, in turn, means that Bella (or the state) is authorized to make Arnold remove his foot by force.

How do Kantian rights compare to Darwallian second-personal authority? Here, it is important to note that Darwall distinguishes between two types of second-personal authority, which correspond to two types of obligation (20I $3 \mathrm{a}$ : 27-28). 'Individual' authority corresponds to directed obligations. If A has an obligation to $\varphi$ which is owed to B, then B has individual authority over that obligation, which enables $\mathrm{B}$ to waive that obligation. If $\mathrm{B}$ does not waive A's obligation, and A fails to $\varphi$ without excuse, then it is apt for B to resent $\mathrm{A}$. By contrast, 'representative' authority corresponds to obligations which are not owed to anyone in particular, instances of what Darwall calls 'moral obligation period' (20I3a: 20). This is an authority that anyone has as a representative member of the moral community. Representative authority does not include the power to waive any obligations. Instead, it is exhausted by the standing to adopt reactive attitudes like blame and indignation toward agents who violate the corresponding obligations. According to Darwall, by adopting these reactive attitudes, 'we add our voice to or second, as it were, a demand that we must presuppose is made of everyone by the moral community or representative persons as such' (2013a: 37). 
If one is looking for the equivalent of Kantian rights in Darwall's framework, individual second-personal authority is the most natural candidate. For one thing, like Kantian rights, individual authority corresponds to directed obligations. For another, both Kantian rights and individual authority are discretionary-while Kantian rights are attached to the option to enforce an obligation, individual authority comes with the option to waive an obligation. Indeed, Darwall thinks that individual authority is necessary, though perhaps not sufficient, for having a right (20г3a: 28nIo). Thus, if Darwall held that individual authority is prior to moral obligations, his account would perhaps seem to parallel the view that rights are prior to duties. To the contrary, however, Darwall argues that representative authority, and thus moral obligation period, is prior to individual authority (2013a: 38-39).

To illustrate this, I return to the case of Arnold and Bella. Arguably, Arnold's obligation to remove his foot is owed to Bella. Accordingly, Bella has individual authority over this obligation. But, as I showed above (in section I), Bella's authority to make demands on Arnold presupposes that Arnold can address these demands to himself from within the second-person standpoint. However, a demand is addressable from within the second-person standpoint only if all persons, qua participants in second-personal address, can legitimately hold each other accountable for compliance with it, when placed in the relevant circumstances (Darwall 2006: 59). Accordingly, the authority that Arnold exerts over himself when he holds himself accountable is not individual authority but the authority of a representative member of the moral community. It follows that Bella's individual authority over Arnold presupposes Arnold's representative authority over himself. Crucially, this also means that Bella's individual authority presupposes that it would be wrong period if Arnold failed to withdraw his foot. In other words, Bella's individual authority presupposes that Arnold is under a moral obligation period to withdraw his foot (Darwall 2013a: 39).

I have shown that, while individual authority might seem to correspond to Kantian rights, this is not the type of second-personal authority that the second-personal account regards as prior to moral obligation. What about representative authority? I argue that, while representative authority is in a sense prior to moral obligations within the second-personal account, this does not threaten the Kantian doctrine of the primacy of duties. The reason is that the role played by representative authority and the associated reactive attitudes within the second-personal account is different from the role played by rights, and the activity of claiming them, within Kant's moral theory.

As noted above, Kantian rights belong to the domain of juridical lawgiving, which is conceptually linked to the authorization of coercion. Therefore, claiming a Kantian right necessarily involves an invocation of the authorization to use coercion. It can also involve appealing to the agent's respect for the moral law, and thus to her autonomy of the will, but it need not (Kant I996b: 389 [MM 6:232]). This is because coercion provides a sufficient incentive to fulfil a juridical duty, which is after all only concerned with external actions (see Kant I996b: 383-84 [MM 6:2I9]). Consequently, claiming a Kantian right can in principle be an instance of the goading type of behavior that Darwall distinguishes from 
genuine second-personal address. As I explained in section I, when we goad an agent, we aim to get her to act in a certain way, by appealing to the agent's independent evaluation of states of affairs.

By contrast, when we hold an agent accountable by adopting reactive attitudes like blame or indignation toward her, thus invoking our representative authority to demand that she $\varphi$, we presuppose that any second-personally competent being, including the agent herself, could make the same demand of her. But, according to Darwall, this in turn presupposes that our demand is warranted by the categorical imperative and that, consequently, the agent could comply with it by determining herself by the mere form of law. Far from invoking an external authority and incentive, then, representative authority directly appeals to the agent's internal motivational capacities, particularly her will's capacity to be a law to itself.

\subsection{Imperfect Duties}

The second agent-centered feature of Kant's moral theory that the second-personal account allegedly abandons is the category of imperfect duties (Timmermann 20I4: I33-36). The difference between perfect and imperfect duties is that, while perfect duties prohibit all maxims that would have us perform a certain act-type, $\psi$, imperfect duties command the adoption of a certain maxim (see Kant I99b: 52 I [MM 6:390]). As a result, a perfect duty yields one and the same token obligation (not to $\psi$ ) under all circumstances. Imperfect duties, by contrast, only provide 'grounds of obligation' that need to be applied to a given set of circumstances to determine which token obligation they yield, if any (Kant I996b: 378-79 [MM 6:224]; see Timmermann 20I3). Following Timmermann, I am here distinguishing between 'duties', understood as 'general prescriptive laws or rules that provide the matter of what ought to be done' and 'obligations', understood as 'individual cases of being morally bound to do something' (Timmermann 2013: 42-43; see also Kant I996b: 377 [MM 6:222]).

Timmermann argues that Kantian imperfect duties 'sit uneasily with second-personal claims' because 'for Kant rightful second-personal claims are indigenous to the sphere of strict or juridical duty' (20I4: I34). Here Timmermann again assumes that second-personal authority plays the role of Kantian rights. Consequently, he assumes that the second-personal account characterizes 'censure' or 'punishment' as appropriate responses to the violation of any obligation (2OI4: I34). Timmermann rightly points out that this view of moral obligations cannot accommodate imperfect duties because, unlike the performance or omission of external acts, the adoption of a maxim cannot be effected from the outside, as it were. He writes, 'When I decide to comply with an imperfect obligation I must do so, in a strong sense, of my own accord. That is why I acquire some "merit" with regard to the beneficiary . . . and why he owes me gratitude in return' (Timmermann 20I4: I35). I already rejected the assumption that second-personal authority corresponds to Kantian rights in the previous subsection. The type of second-personal authority that the second-personal account takes to be prior to moral obligations does not essentially involve an appeal to external coercion. Instead, it is the authority to 
adopt reactive attitudes like blame, which directly appeal to autonomy of the will, and thus summon the agent to comply 'of her own accord'.

Timmermann thinks that even blame is an inappropriate response to the violation of an obligation of imperfect duty (2OI4: I34-35). However, Timmermann is not using 'blame' in the same sense as Darwall. Timmermann supposes that an agent is blameworthy for $\psi$-ing only if $\psi$-ing renders her an overall 'evil or vicious' person (20I4: I35). By contrast, Darwall writes that '[r]eactive attitudes... concern themselves not with a person's overall agency, but specifically with his conduct with respect to claims or demands that other persons have standing to make of him' (Darwall 2006: 80). Thus, even if Timmermann is right to note that blame in his sense is an inappropriate response to the violation of an imperfect duty, it does not follow that blame in the sense invoked by the second-personal account is an inappropriate response.

One might nevertheless wonder if the second-personal account can accommodate the link between imperfect duties and gratitude. According to Kant, if an agent fulfils her imperfect duty (for example, of beneficence) with respect to some particular person (for example, by aiding her), then that person owes gratitude to the agent (Kant 20II: 89 [G 4:430]; Kant I996b: 568, 57I-74 [MM 6:448, 6:452-55]). But, Timmermann asks, '[w]hy should anyone be grateful to a benefactor who is merely responding to pre-existing second-personal claims' (20I4: I35)?

In response, I note two things. First, accommodating the link between imperfect duties and gratitude is not especially challenging for the second-personal account. How hard it is to accommodate this link depends, not on whether we adopt the second-personal account, but on how we interpret Kant's account of imperfect duties. To see this, compare what I call the strict reading and the lax reading. On the strict reading, which is favored by Timmermann, imperfect duties generate token obligations that are just as 'unconditional' and 'non-negotiable' as those generated by perfect duties (Timmermann 20I4: I35; see also Timmermann 2005 ). If the strict reading is correct, the second-personal account implies that we are accountable for fulfilling the token obligations generated by imperfect dutiesthat is, we are blameworthy if we violate them without excuse. This might seem to pose a challenge when it comes to accommodating the link between imperfect duty and gratitude. However, this challenge is no more serious than the challenge that the strict reading, by itself, generates. After all, saying that an agent deserves gratitude for doing what she had an 'unconditional', 'non-negotiable' obligation to do is no less problematic than saying that an agent deserves gratitude for doing what she was accountable for doing. On the lax reading, by contrast, imperfect duties are significantly less demanding than perfect duties (see Hill 2002: 20I-43). On this reading, imperfect duties make room for actions that are good but not obligatory. If this is correct, then the second-personal account does not imply that our imperfect duties render us accountable for acting in some specific way. Accordingly, there is also no challenge regarding the link between imperfect duty and gratitude on this reading.

Second, the challenge regarding the link between imperfect duties and gratitude that-supposing the strict reading is true-arises for the second-personal account is not as serious as it might seem. When Timmermann formulates this challenge, 
he seems to assume that gratitude is an appropriate response to an agent's $\varphi$-ing only if the agent would not be blameworthy for failing to $\varphi$ without excuse. However, this assumption seems false. Suppose that I could save a child's life at no significant cost to myself. Suppose further that, by doing so, I would be neither violating any perfect duty nor neglecting any of my imperfect duties. On the strict reading, my imperfect duty of beneficence generates a token obligation to rescue the child under these circumstances (see Timmermann 2005: 20-2I; 20I4: I34). It seems to follow that I violate my imperfect duty of beneficence if I fail to rescue. Accordingly, it seems plausible that I will be blameworthy for failing to help without excuse. Yet, it also seems appropriate (for the parents of the child, at least) to show gratitude toward me if I save the child. Hence, the fact that gratitude can be an appropriate response to an agent's $\varphi$-ing in a situation where, according to the secondpersonal account, the agent would have been blameworthy for failing to $\varphi$ without excuse is not a reason to reject the second-personal account. This seemingly contradictory constellation of attitudes is not just an implication of the second-personal account (when conjoined with the strict reading) but a feature of our actual moral practice.

Timmermann might respond that, while I would be blameworthy in this situation, the reason is not that I fail to help on this particular occasion but that-as my failure to help reveals-I have adopted a maxim of never helping others, which makes me 'morally vicious' (20I4: I35nII). I have two replies. First, as I noted above, Timmermann is not using 'blame' in the same sense as the second-personal account. Hence, even if I am not blameworthy for failing to help in Timmermann's sense, I might still be blameworthy in Darwall's sense. Second, the second-personal account can concede that, strictly speaking, blame is occasioned by an agent's will rather than by her external acts (see Darwall 2008: I95). In any case, this does not seem to decrease the tension between our judgments of blameworthiness and the aptness of gratitude.

\section{$3 \cdot 3$ Duties to Oneself}

The third aspect of Kant's moral philosophy that the second-personal account is accused of abandoning by virtue of its supposed association with a narrow subset of duties is the category of duties to oneself (Timmermann 20I4: I3I-33). In Kant's moral system, duties to oneself parallel, in structure and importance, duties to others.

In a sense, duties to oneself are even more important than duties to others. After all, according to Kant, 'I can recognize that I am under obligation to others only insofar as I at the same time put myself under obligation' (I996b: 543 [MM $6: 4 \mathrm{I} 7-\mathrm{I} 8]$ ). However, this sense of 'duties to oneself' is to be distinguished from the one that is relevant here: while in this wide sense all duties are ultimately duties to oneself, the sense that is relevant here serves to contrast duties 'to ourselves' from those 'to other human beings' (Kant 2OII: 7I [G 4:42I]). Moreover, I already showed that the second-personal account can accommodate duties to oneself in the wide sense in section 2.

About the prospect of accommodating duties to oneself within the second-personal account, Timmermann writes, 'As the name indicates, duties to 
oneself are irreducibly first-personal. They need not involve any person other than the agent. Moreover, they solely depend on the agent's will and cannot be externally enforced.... They are not second-personal' (20I4: I32).

I have already shown that the second-personal account is not committed to the external enforceability of all obligations. One might nevertheless wonder how duties to oneself could be second-personal given that, as Timmermann notes, they need not involve another person. However, as I noted in section 2, the second-personal account claims that obligations presuppose the agent's ability to hold himself accountable for complying with them. This implies that second-personal address does not require interaction with another person. As Darwall puts it, "“second person" does not entail "second party" (20IOa: 2I7).

Yet, the possibility of addressing ourselves second-personally might not seem to show that the second-personal account can accommodate duties to oneself. For all that has been said so far, this kind of self-address might simply be the internal counterpart, a mere reflection, of our duties to others. What might seem to be missing is a demonstration that the second-personal account can attribute symmetrical roles, in moral reasoning, to ourselves and other persons. However, it is not clear why the second-personal account should not be able to do so. As Timmermann notes, by endorsing the categorical imperative as the supreme principle of morality, this account seems committed to this symmetry (20I4: I32).

Moreover, Darwall endorses the Kantian duty to avoid servility (see Kant I996b: 556-59 [MM 6: 434-37]). He writes that '[g]iving little weight to one's own wishes and values, by being inappropriately deferential to those of others, can be. . . a failure to respect ourselves' (Darwall 2013b: I2I; also see Darwall 2008: I93-94). And, indeed, this seems to follow from the second-personal account. To see this, recall that, for Bella's demand of Arnold to be legitimate, Arnold must be able to address this demand to himself from within the second-person standpoint. And this, in turn, gives rise to a legitimate demand on Arnold's part: that demands made of him be justifiable from within the second-person standpoint (Darwall 2006: 27I-74). Thus, one way for Arnold to act contrary to what is justifiable from within the second-person standpoint-and thus to act wrongly-is to neglect a demand of Bella's that he can address to himself. But another way to act wrongly is to comply with a demand of Bella's that he cannot address to himself and which, to the contrary, he can demand not to be subject to.

Finally, the possibility to hold ourselves accountable through attitudes of self-reproach seems to suggest that obligations owed to ourselves are congenial to the second-personal account. Indeed, several theorists, myself included, invoke the second-personal account in arguments for the possibility and existence of obligations to oneself (Cholbi 20I5, 20I8; Rosati 20II; Schaab 20I9, 202I; Schofield 2015, 2019).

\section{Respect}

The third challenge to the thesis that the second-personal account is congenial to Kant's moral theory is concerned with the feeling of respect, which arises from 
our awareness of the principle of pure practical reason and serves as the motive for actions done from duty.

To discuss the role of respect within Kant's moral theory, it is helpful to introduce Darwall's distinction between two kinds of respect (1977; 2006: 122-26). Appraisal respect amounts to 'an assessment of someone's conduct or character or of something that somehow involves these' (2006: I22). In the case of morality, we respect someone in the appraisal sense when we judge them to be a morally good agent (2006: I22). Recognition respect, by contrast, 'concerns not how something is to be evaluated or appraised, but how our relations to it are to be regulated or governed' (2006: I23). Relatedly, '[t]he object of recognition respect is not excellence or merit; it is dignity or authority' (2006: I 22).

As I explain in more detail below, Darwall's claim that the vindication of the categorical imperative must proceed via the notion of second-personal authority, implies that the motive of duty involves recognition respect for persons. However, some theorists argue that, for Kant, the motive of duty is recognition respect for the law, not for persons (see, for example, Timmermann [2014: I38-40]; Sensen [20II: II 8-22]). Their arguments can be summarized as follows. Whenever Kant mentions respect for persons, the kind of respect he has in mind is either appraisal respect or something else altogether, but not recognition respect. For example, when Kant writes that '[a]ll respect for a person is actually only respect for the law (of righteousness etc.) of which he gives us the example', he is saying that we respect others in the appraisal sense insofar as they display a morally good character (Kant 20II: 3 In [G 4:40I, footnote]). And when Kant introduces 'duties of respect for other human beings', he is using 'respect' in an altogether different sense (I996b: 48 I [MM 6:465]). After all, Kant is not here concerned with a feeling of respect-that is, a recognition or appraisal of an authority or quality that persons have. By contrast, he is concerned with the way the moral law commands us to treat or regard persons. Accordingly, the 'respect' involved in duties of respect does not play the role of motivating moral action in general. Instead, it is but one part of the content of the moral law.

One way to reply to these arguments is by providing textual evidence that Kant himself appeals to recognition respect for persons after all (see, for example, Darwall 2008). However, I pursue a different strategy here. I argue that, regardless of whether Kant's own writings feature recognition respect for persons, this notion is philosophically congenial to Kant's moral theory. Indeed, there is reason to think that Kant is independently committed to viewing the motive of duty as recognition respect for persons as well as the law. My argument unfolds in two steps. In this section, I show how the second-personal account abandons the dichotomy between respect for persons and respect for the law. In the next section, I show how Kant might be independently committed to a similar view.

The second-personal account abandons the dichotomy between respect for persons and respect for the law by depicting the motive of duty as a feeling of recognition respect both for persons and for the law. While the second-personal account acknowledges that the feeling of respect arises from the agent's encounter of the moral law within her own practical reason, it asserts that this encounter must involve the agent's awareness of being accountable for acting on the moral 
law. On the second-personal account, this link to accountability is part of the very concept of moral obligation and plays an essential role in vindicating the categorical imperative as the supreme moral principle. Therefore, according to the second-personal account, recognition respect for the moral law, as a matter of conceptual entailment, is recognition respect for the equal second-personal authority of all members of the moral community.

One might wonder how it is even possible that respect for the law is respect for persons. At first glance, respect for the law involves submission under a principle, not recognition of others. Here, it is crucial to understand that the moral community, according to the second-personal account, is not a group of concrete individuals. Darwall writes, '[T] he moral community as I understand it is not any actual community composed of actual human beings. It is like Kant's idea of a 'realm of ends,' a regulative ideal that we employ to make sense of our ethical thought and practice' (2007: 64).

To see this, recall that an agent is accountable for complying with a demand only if she can hold herself accountable for complying with it from within the second-person standpoint. But this, in turn, implies that she is accountable for complying with the demand only if any second-personally competent being as such could hold itself accountable for complying with it. This evokes Kant's notion of the kingdom of ends: '[The dignity of the rational being] brings with it that it must always take its maxims from the point of view of itself, but also at the same time of every other rational being as legislating (which are therefore also called persons). Now in this way a world of rational beings (mundus intelligibilis) as a kingdom of ends is possible, and possible through their own legislation of all persons as members' (2OII: IO5 [G 4:438]).

To say that to respect the law is to respect the second-personal authority of the moral community, then, is not to say that the motive of duty comes down to respect for the contingent, empirical demands made by actual human beings. Rather, it comes down to respect for autonomy of the will, and thus-given that autonomy amounts to the capacity to co-legislate from a shared second-personal perspective-to respect for the equal dignity of all second-personally competent beings as such.

Indeed, on the second-personal account, person is an irreducibly second-personal concept too: to be a person just is to have the authority to demand compliance with principles that are justifiable from within the second-person standpoint (Darwall 2006: 80, I 26). Thus, the concept of the person forms part of an 'interdefinable circle' of 'irreducibly second-personal concepts', which includes the concepts of legitimate demand and second-personal authority (2006: II-I2). This is what most fundamentally underpins the second-personal account's identification of respect for the law with respect for persons. If the law is the principle of obligation, where obligation is conceptually tied to our accountability, which is in turn conceptually tied to persons, then to respect the law just is to respect persons. Indeed, we might say that the law is the formal principle, not only of practical reason, but also of the person.

One might object that, while respect for the law might involve respect for persons indirectly, respect for the law does not seem to relate us to persons directly. However, 
even when we encounter the moral law within our own practical reason, without being addressed by another, we address ourselves by invoking the representative authority of persons as such. We might say we are addressed by the very idea or form of the person.

To conclude, the second-personal account undermines the dichotomy between respect for persons and respect for the law. This account implies that the motive of duty involves not only recognition respect for the law, but also-and precisely because it involves recognition respect for the law-recognition respect for persons.

\section{Persons and the Law}

According to the second-personal account, the motive of duty is a feeling of recognition respect for the law and for persons. This suffices to show that this account does not abandon Kant's view that the motive of duty is respect for the law. I now argue that, in addition, there is good reason to think that Kant himself is independently committed to the notion that the motive of duty involves respect for persons and for the law.

As I discussed in the previous section, some authors argue that respect for others figures in Kant's moral theory only in two ways. First, there is a feeling of appraisal respect for the morally good actions of others. Second, there is a duty to respect others, which does not command a feeling but a certain way of treating or regarding others. This picture suggests that persons relate to the law only as agents who are subject to it (and can acquire merit by complying with it) and as patients, whom the law marks out for a certain kind of treatment or regard.

However, this picture does not exhaust the ways in which persons relate to the law in Kant's system. A maxim is compatible with the law if and only if it is compatible with the autonomy of all persons, not because that happens to be the content of the law, but because of what kind of principle the law is: the formal principle of a unified plurality of autonomous wills, 'a merely possible kingdom of ends' (Kant 20I I: IO7

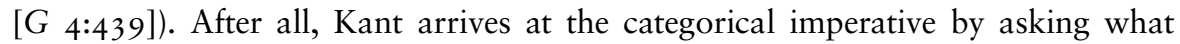
principle could function as a universal law, and thus a law for a potential manifold of reasoners (Kant 20II: 33 [G 4:402]). Thus, other persons do not enter moral reasoning only in a second step, as it were. We might say that persons, qua rational beings endowed with autonomy, are instances of the law. This suggests that, although persons' demands do not create obligations by themselves, they do not merely serve to remind us of our obligations either (pace Sensen 20II: I2I). This strongly suggests that recognition respect for the law is ipso facto also recognition respect for persons. In a similar vein, Francey Russell argues that, while only the law exacts respect, the law 'shows up both in the form of [the] agent's own reason and in the form of other persons' (2020: 274).

Indeed, there is good reason to think that Kant is also committed to the idea that the law is the formal principle of the person. To see this, it is important to understand in what sense the moral law is the formal principle of an autonomous will. The law is constitutive of the activity of autonomous willing in the sense that, if one were not guided by the moral law, one would not count as engaging in this activity. After all, autonomy is 'the characteristic of the will by which it is a law to itself' (Kant 
20II: IO9 [G 4:440], my emphasis). Thus, unlike other candidate moral principles, such as the principle of utility, the moral law is not an external standard against which our maxims and actions are to be measured. Instead, it is an internal standard of autonomous willing, a standard that the autonomous will as such strives to comply with (see Reath 20I3: 223; Sensen 20II: I09-II). This is why the law 'commands neither more nor less than just this autonomy'; it commands that the autonomous will live up to its own ambition of being a law to itself (Kant 20II: IO9 [ $G$ 4:440]). Since it is the possession of an autonomous will that distinguishes 'persons' from 'things', this suggests that the law is the formal principle of the person (Kant 20I I: 85 [G 4:428]). Indeed, Kant writes, '[t]he idea of the moral law alone, with the respect inseparable from it . . is personality itself' (2009: 30 [Rel 6:28]).

One might object that, while there is a sense in which Kant regards the moral law as the formal principle of the person, this does not warrant the conclusion that recognition respect for the law amounts to recognition respect for persons. In some passages, Kant seems to use 'personality' and related terms to denote a characteristic of agents who comply with the moral law. For example, in the Critique of Practical Reason, he writes, 'This idea of personality, awakening respect by setting before our eyes the sublimity of our nature (in its vocation) while at the same time showing us the lack of accord of our conduct with respect to it and thus striking down self-conceit, is natural even to the most common human reason and is easily observed' (I996a: 2 Io [CPrR 5:87], my emphasis).

Similarly, in the Religion within the Bounds of Bare Reason, Kant reserves the term 'personality' for an agent whose 'power of choice' is determined by the law (2009: 30 [Rel 6:27]). He writes, 'since this becomes possible solely through the free power of choice's admitting the moral feeling into its maxim, the constitution of such a power of choice is a good character' (2009: 30 [Rel 6:27], my emphasis).

According to the present objection, while the law is constitutive of personhood, persons are nevertheless to be respected in the appraisal sense only. For the passages above suggest that 'personality' denotes a good moral character, and thus something to be achieved, rather than a standing or authority that all persons as such have.

However, this line of objection creates a puzzle: why does Kant label the phenomenon in question 'personality' rather than 'moral goodness'? The view that the law is the formal principle of the person more generally (as opposed to the morally good person only) accounts for the passages quoted above in a way that solves this puzzle. If striving to comply with the moral law is what makes someone a person, moral goodness is the constitutive aim of personhood. We might then say that an agent who achieves moral goodness thereby realizes his personhood, and thus attains personality in the fullest sense. In this view, although only personality in this fullest sense is an appropriate object of appraisal respect, the moral law is constitutive of personhood in general. Accordingly, persons in general are appropriate objects of recognition respect. Indeed, this view parallels Sensen's account of the related concepts of autonomy, dignity, and ends in themselves as involving two stages: initial and realized (201 I: I69).

The idea that the law is the formal principle of the person also sheds light on Kant's account of conscience. He writes, '[Conscience] is peculiar in that, 
although its business is a business of a human being with himself, one constrained by his reason sees himself constrained to carry it on as at the bidding of another person' (I996b: 560 [MM 6:438]). This passage suggests that the moral law itself, when encountered within our own practical reason, takes the guise of a person. If the law is the formal principle of the person, this should not surprise us.

I do not claim that Kant is committed to the view that the law is the formal principle of the person for the same reason as the second-personal account. I do, however, claim that the second-personal account's commitment to this view, by itself, need not constitute a departure from Kant's moral theory. Furthermore, as my argument in this section suggests, the second-personal account illuminates some hitherto underexamined elements of Kant's moral theory.

\section{Conclusion}

The second-personal account is not identical to Kant's moral theory. However, it is far more congenial to Kant's views than Darwall's Kantian critics believe. First, it does not abandon the Kantian notion that moral obligation has its source in pure practical reason. It rather supplements that notion with the claim that pure practical reason is inseparably tied to relations of accountability. Second, it accommodates agent-centered features of Kant's moral theory, such as the primacy of duties over rights, imperfect duties, and duties to self. Third, it is compatible with the identification of the motive of duty with respect for the law. Indeed, the second-personal account even sheds new light on Kant's own view by serving as an inspiration for the interpretation that the moral law is the formal principle of the person and, therefore, to respect the law is to respect persons.

JANIS DAVID SCHAAB 우

UNIVERSITY OF GRONINGEN

j.d.schaab@rug.nl

\section{References}

Bacin, Stefano. (2015) 'Kant's Idea of Human Dignity: Between Tradition and Originality'. Kant-Studien, 106, 97-106.

Cholbi, Michael. (2015) 'On Marcus Singer's “On Duties to Oneself”'. Ethics, I 25,85 I-53.

Cholbi, Michael. (201 8) 'Paternalism and Duties to Self.' In Kalle Grill and Jason Hanna (eds.), The Routledge Handbook of the Philosophy of Paternalism (Abingdon: Routledge), I०8-18.

Darwall, Stephen L. (I977) 'Two Kinds of Respect', Ethics, 88, 36-49.

Darwall, Stephen L. (2006) The Second-Person Standpoint: Morality, Respect, and Accountability. Cambridge, MA: Harvard University Press.

Darwall, Stephen L. (2007) 'Reply to Korsgaard, Wallace, and Watson'. Ethics, I I 8, 52-69.

Darwall, Stephen L. (2008) 'Kant on Respect, Dignity, and the Duty of Respect'. In Monika Betzler (ed.), Kant's Ethics of Virtue (Berlin: De Gruyter), I75-200.

Darwall, Stephen L. (2009) 'Why Kant Needs the Second-Person Standpoint'. In Thomas E. Hill (ed.), The Blackwell Guide to Kant's Ethics (Oxford: Wiley-Blackwell), I38-57.

Darwall, Stephen L. (20Iоa) 'Precis: The Second-Person Standpoint'. Philosophy and Phenomenological Research, 8I, 216-28. 
Darwall, Stephen L. (20Iob) 'Reply to Schapiro, Smith/Strabbing, and Yaffe'. Philosophy and Phenomenological Research, 8 I, 253-64.

Darwall, Stephen L. (20I za) 'Bipolar Obligation'. In Darwall, Morality, Authority, and Law: Essays in Second-Personal Ethics I (Oxford: Oxford University Press), 20-39.

Darwall, Stephen L. (20I3b) 'The Value of Autonomy and Autonomy of the Will'. In Darwall, Morality, Authority, and Law: Essays in Second-Personal Ethics I (Oxford: Oxford University Press), I I 4-33.

Ebels-Duggan, Kyla. (2009) 'Moral Community: Escaping the Ethical State of Nature'. Philosophers' Imprint, 9, article no. 8. http://hdl.handle.net/2027/spo.352I354.0009.008

Flikschuh, Katrin. (2017) What Is Orientation in Global Thinking? A Kantian Inquiry. Cambridge: Cambridge University Press.

Grenberg, Jeanine. (2013) Kant's Defense of Common Moral Experience: A Phenomenological Account. Cambridge: Cambridge University Press.

Hill, Thomas E. Jr. (2002) Human Welfare and Moral Worth: Kantian Perspectives. Oxford: Clarendon Press.

Hope, Simon. (2013) 'Subsistence Needs, Human Rights, and Imperfect Duties'. Journal of Applied Philosophy, 30, 88-100.

Kant, Immanuel. (I996a) 'Critique of Practical Reason (I788)'. In Mary Gregor (ed. and trans.) Practical Philosophy (Cambridge: Cambridge University Press), I33-27I.

Kant, Immanuel. (I996b) 'The Metaphysics of Morals (1797)'. In Mary Gregor (ed. and trans.) Practical Philosophy (Cambridge: Cambridge University Press), 353-603.

Kant. Immanuel. (2009) Religion within the Bounds of Bare Reason. Edited and translated by Werner S. Pluhar. Cambridge: Cambridge University Press.

Kant, Immanuel. (20I I) Groundwork of the Metaphysics of Morals: A German-English Edition. Edited and translated by Mary Gregor and Jens Timmermann. Cambridge: Cambridge University Press.

Korsgaard, Christine M. (1996) The Sources of Normativity. Cambridge: Cambridge University Press.

Korsgaard, Christine M. (2007) 'Autonomy and the Second Person Within: A Commentary on Stephen Darwall's The Second-Person Standpoint'. Ethics, I I 8, 8-23.

Korsgaard, Christine M. (2009) Self-Constitution: Agency, Identity, and Integrity. Oxford. Oxford University Press.

O'Neill, Onora. ( I996) Towards Justice and Virtue: A Constructive Account of Practical Reasoning. Cambridge: Cambridge University Press.

Pauer-Studer, Herlinde. (20I0) ‘The Moral Standpoint: First or Second Personal?’ European Journal of Philosophy, I 8, 296-3 го.

Reath, Andrews. (2013) 'Formal Approaches to Kant's Formula of Humanity'. In Mark Timmons and Sorin Baiasu (eds.), Kant on Practical Justification: Interpretive Essays (Oxford: Oxford University Press), 20I-28.

Ripstein, Arthur. (2009) Force and Freedom: Kant's Legal and Political Philosophy. Cambridge, MA: Harvard University Press.

Rosati, Connie. (20 I I) 'The Importance of Self-Promises'. In Hanosh Sheinman (ed.), Promises and Agreements: Philosophical Essays (New York: Oxford University Press), I $25-55$.

Ross, W. D. (2002) The Right and the Good. Edited by Philip Stratton-Lake. Oxford: Oxford University Press.

Russell, Francey. (2020) 'Kantian Self-Conceit and the Two Guises of Authority'. Canadian Journal of Philosophy, 50, 268-83.

Schaab, Janis David. (2019) 'Commitment and the Second-Person Standpoint'. Zeitschrift für philosophische Forschung, 73, 5I I-32.

Schaab, Janis David. (202 I) 'On the Supposed Incoherence of Obligations to Oneself'. Australasian Journal of Philosophy, 99, I75-89.

Schapiro, Tamar. (2010) 'Desires as Demands: How the Second-Personal Standpoint Might Be Internal to Reflective Agency'. Philosophy and Phenomenological Research, 81, 229-36.

Schofield, Paul. (2015) 'On the Existence of Duties to the Self (and Their Significance for Moral Philosophy'. Philosophy and Phenomenological Research, 90, 505-28. 
Schofield, Paul. (2019) 'Practical Identity and Duties to the Self'. American Philosophical Quarterly, $56,219-32$.

Sensen, Oliver. (20I I) Kant on Human Dignity. Berlin: De Gruyter.

Strawson, P. F. (I962) 'Freedom and Resentment'. Proceedings of the British Academy, 48, I-2 5.

Timmermann, Jens. (2005) 'Good But Not Required?-Assessing the Demands of Kantian Ethics'. Journal of Moral Philosophy, 2, 9-27.

Timmermann, Jens. (2013) 'Kantian Dilemmas? Moral Conflict in Kant's Ethical Theory'. Archiv für Geschichte der Philosophie, 95, 36-64.

Timmermann, Jens. (2014) 'Kant and the Second-Person Standpoint'. Grazer Philosophische Studien, 90, I3 I-47.

Willaschek, Marcus. (1997) 'Why the Doctrine of Right Does not Belong in the Metaphysics of Morals: On Some Basic Distinctions in Kant's Moral Philosophy'. Jahrbuch für Recht und Ethik, 5, 205-27. 